\title{
Research on Development Mode of Intelligent Rural Tourism under Digital Background
}

\author{
Chunlin Zhou \\ School of Tourism and Event, Henan University of Economics and Law, China \\ E-mail: zhouchunlin@huel.edu.cn \\ http://www.huel.edu.cn
}

Keywords: digital background; smart village; tourism development

Received: July 15, 2019

\begin{abstract}
Intelligent rural tourism rapidly emerged under the digital background in China after the reform and development. Driven by the theme of China tourism administration's smart rural tourism year under digital background, the digital background smart rural tourism market has entered a period of vigorous development, accelerating the integration of tourism and agriculture, with forestry and other related industries. Since the late 1990s, China's rural areas have experienced four stages of spontaneous development, quantity expansion, standardized development and quality improvement. After more than 20 years' active exploration, China has established a development path with Chinese characteristics and a smart rural tourism model under digital background.
\end{abstract}

Povzetek: Opisan je razvoj inteligentnega kmečkega turizma na Kitajskem z metodami UI.

\section{Introduction}

Intelligent rural tourism rapidly emerged under the digital background in China after the reform and development. Driven by the theme of China tourism administration's smart rural tourism year under digital background, the digital background smart rural tourism market has entered a period of vigorous development, accelerating the integration of tourism and agriculture, with forestry and other related industries and industries. Since the late 1990s, China's rural areas have experienced four stages of spontaneous development, quantity expansion, standardized development and quality improvement [1] [2]. After more than 20 years' active exploration, China has established a development path with Chinese characteristics and a smart rural tourism model under digital background.

\section{Research on the development mode of intelligent rural tourism under digital background}

\subsection{Analysis of the development status of digital rural intelligent tourism in China}

In 2009, in order to upgrade China's smart rural tourism under digital background, the National Tourism Administration introduced a variety of new digital background smart rural tourism on the basis of provincial smart rural tourism with the digital background. The new concept of smart rural tourism is of great significance for enhancing the scale and quality of digital rural tourism [3]. In recent years, the digitized background of smart rural tourism reception capacity and income in China as shown in Table 1.

\begin{tabular}{|c|c|c|c|}
\hline Time & $\begin{array}{c}\text { Smart rural } \\
\text { tourism } \\
\text { reception (ten }\end{array}$ & $\begin{array}{c}\text { Smart rural } \\
\text { tourism } \\
\text { employees (ten }\end{array}$ & $\begin{array}{c}\text { Smart } \\
\text { rural tourism } \\
\text { income }\end{array}$ \\
\hline 2010 & 1404 & 62 & 251 \\
\hline 2011 & 157 & 64 & 304 \\
\hline 2012 & 162 & 68 & 359 \\
\hline 2013 & 168 & 78 & 376 \\
\hline
\end{tabular}

Table 1: Intelligent rural tourism recipients, employees and income in China.

An investigation into the smart rural tourism in China found that the digital background smart rural tourism products presented traditional singleness and lack of diversity. The overall level stayed at a low level of offering accommodation, agricultural products, parties and souvenirs [4]. The number of smart rural tourism and

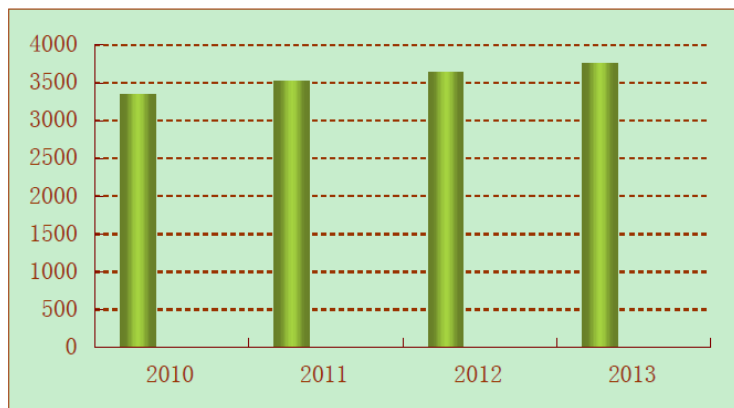

Figure 1: Number of intelligent rural tourism receptionists in China (Unit: 100,000). 
the number of receptionists in China in recent years is shown in Figure 1.

\subsection{Digital background definition of intelligent rural tourism development model}

This paper defines the digital background smart rural tourism development model as the chain-type relationship formed by certain departments supporting digital rural intelligence tourism activities through certain economic relationships [5]. The smart rural tourism development model comprises of a horizontal extension, vertical associated function chain, product chain and cultural value chain. It appears as a network structure consisting of horizontal cooperation and vertical supply and demand. Its expression is as follows:

$$
T=H(i, j, s, b)
$$

In this concept, there are the two points to be explained. For one thing, some departments on the digital background smart rural tourism development model are horizontally cooperative. Each industry in the smart rural tourism development model can directly provide tourism products for tourists, but they need to work together to provide tourists with complete tourism product. For another, if the collaboration is not effective, the poor performance of one of the industries will weaken the development pattern of the entire digital background smart rural tourism [6]. The change relationship is as shown in formula (2) as follows:

$$
\mu A_{i}(x)=e^{-\frac{(x-a)^{2}}{2 b^{2}}}
$$

\subsection{Digital background characteristics of intelligent rural tourism development model}

(1) Reticulation structure

The traditional mode of manufacturing rural tourism development is based on the vertical industrial linkage of the product process division. Products are processed through upstream, middle, and downstream enterprises and finally presented to consumers [7]. The background of the digital background smart rural tourism development model includes not only the vertical supply and demand relationship, but also the horizontal collaboration relationship. Its mathematical expression is as follows:

$$
C=\left(Q, F_{1}, F_{2}, F_{r}\right)
$$

Digital background intelligent rural tourism products have comprehensive features [8]. Tourists enjoy a range of tourism services from the time they leave their place of residence for the digital background smart rural tourism destinations. In other words, different from the final products of the rural tourism development model for the consumer, the various departments on the digital background smart rural tourism development model can directly provide tourism consumers with tourism products.
However, each department can only provide part of the product [9]. If tourists are to be able to experience the full digital background smart rural tourism products, they need effective collaboration and cooperation among all sectors of the rural tourism development model. The main coordination method is shown in formula (4) as follows:

$$
P\left(A_{l+s} \mid o_{l}\right)=\prod_{s=1}^{s}\left(\frac{k_{l+s}}{n_{l+s}}\right)
$$

(2) The characteristics of digital background intelligent rural tourism

The rural nature is the essential attribute of the digital background intelligent rural tourism. The reality includes the rural nature of tourism resources, tourism products, tourism market and tourism benefits; the rural nature can be divided into rural culture and rural landscape [10]. The digital background essence of the rural tourism is the rural culture. The rural culture with nationality, history and region is the essential attribute of the digital background intelligent rural tourism. Rural culture as a concrete description is the property of the digital background intelligent rural tourism. Its mathematical expression is as follows:

$$
g=\sum_{i, j} b_{i j} q_{i} q_{j}
$$

The determination of core value of the digital background smart rural tourism development model is conducive to a clear direction for development. As to the core of the general tourism rural tourism development model, the traditional view is that travel agencies are the hubs linking the six major elements of tourism, while under the digital background, the reconstruction of the value chain of the tourism industry aims at reconfirming the core node of the chain, and that is, establishing a tourism industry value chain model with tourism sites and tourist attractions as the core [11]. The core of tourism and rural tourism development model is tourism and tourist attractions, and the tour experience of tourism sites and tourist attractions. The core value is tourism and rural tourism development model. However, the digital background smart rural tourism is a more special form of tourism. the mathematical expressions of the four traditional forms of digital rural tourism in China and eight new forms of business are as follows:

$$
M S K=(f, w)
$$

People choose smart rural tourism for various reasons, some to taste rural food, some to experience agricultural activities, and some to enjoy the rural scenery. That is to say, people choose smart rural tourism for the specific rural cultural atmosphere. It is a kind of cultural yearning for rural food culture, agricultural culture, and rural landscape culture. Therefore, this paper holds that the core value of the digitalized background intelligent rural tourism development model should be rural cultural experience. The value system centering on the intelligent rural tourism cultural experience is the basis for realizing the value-added rural tourism development model [12]. Culture is a description of a special way of life, and then the digital background smart rural tourism is a description of the special rural lifestyle. The rural culture includes 
rural food culture, rural living culture, rural landscape culture, agricultural culture, rural product culture, rural entertainment in terms of culture and so on, and these aspects are all examples of rural special lifestyles as shown in Table 2:

\begin{tabular}{|c|c|}
\hline $\begin{array}{c}\text { Rural cultural } \\
\text { experience } \\
\text { manifestation }\end{array}$ & Performance description \\
\hline $\begin{array}{c}\text { Rural food } \\
\text { culture experience }\end{array}$ & $\begin{array}{c}\text { Including rural eating habits, } \\
\text { methods, and allegorical relations } \\
\text { with literature and art }\end{array}$ \\
\hline $\begin{array}{c}\text { Rural } \\
\text { characteristic folk } \\
\text { customs experience }\end{array}$ & $\begin{array}{c}\text { Including the selection of rural } \\
\text { residential sites, construction } \\
\text { techniques, architectural structures, } \\
\text { spatial layout, and aesthetic ideas, } \\
\text { religious concepts, etc. }\end{array}$ \\
\hline $\begin{array}{c}\text { Rural landscape } \\
\text { / pastoral scenery } \\
\text { experience }\end{array}$ & $\begin{array}{c}\text { Different from the } \\
\text { comprehensive performance of } \\
\text { various phenomena such as the } \\
\text { humanities, society, and nature of }\end{array}$ \\
\hline $\begin{array}{c}\text { Rural } \\
\text { entertainment } \\
\text { culture / farming } \\
\text { activities experience }\end{array}$ & $\begin{array}{c}\text { Including picking, fishing and } \\
\text { other farming or recreational } \\
\text { activities. }\end{array}$ \\
\hline
\end{tabular}

Table 2: Multi-dimensional performance of core values of smart rural tourism development model with digital background.

(3) The characteristics of China's intelligent rural tourism evaluation

There are many perspectives on intelligent rural tourism evaluation. For example, the stability of rural tourism development model can be evaluated from the government's point of view. The cooperation of rural tourism development model can be evaluated from the perspective of the enterprise [13]. With tourism development model for performance evaluation, this paper chooses to evaluate the rural tourism development model of China's digital background smart rural tourism from the perspective of tourists. There are two main advantages in selecting tourist perspectives: firstly, assessing the advantages and disadvantages of the rural tourism development model from the tourists' perspective is closer to the target market; secondly, the use of questionnaires on the tourists is for the measurement of rural tourism development model, and the result is more objective and easier to measure. This paper selected digital background smart rural tourism catering, digital background smart rural tourism accommodation, digital background smart rural tourism products, digital background smart rural tourism scenic spots, digital background smart rural tourism traffic, digital background smart rural tourism entertainment activities for the project indicator layer, and there are several factor layers under the indicator layer, as shown in formula (7) as follows:

$$
\Pi\left(a_{i}\right)=Y\left(a_{i} \mid \operatorname{Pr} e\left(a_{i}\right)\right)
$$

\subsection{Data analysis of smart rural tourism development model under digital background}

\section{(1) Questionnaire design}

The questionnaire in this paper is divided into two parts: firstly, the demographics and travel characteristics of tourists, including the demographic characteristics of tourists and tourists' travel characteristics. Secondly, the development model and importance. Development model survey factors use the five-point scale as the evaluation criteria for index evaluation. The survey objectives are: development model and importance. This paper focuses on field surveys of smart rural tourism sites with digital backgrounds in China. 288 questionnaires were distributed and 268 valid questionnaires were collected.

(2) Reliability analysis

A questionnaire with good reliability shows good stability and consistency. Reliability analysis is the analysis method that obtains the reliability of the questionnaire through the evaluation method, and uses the reliability to evaluate whether the questionnaire has good reliability and stability [14]. In general, the same question in the questionnaires of different subjects tends to be consistent, indicating that there is no large sample-tosample error in the questionnaire survey and the reliability of the questionnaire is higher, and the reliability is lower. Reliability generally uses $\alpha$ coefficient as its evaluation index. The coefficient is generally between 0 and 1 [15]. The higher the reliability, the closer of $\alpha$ coefficient is to 1 , which means that the more stable the questionnaire, and the mathematical expression is as follows:

$$
p=\left(\alpha, v, h, h^{w}, \ldots, h^{w_{n}}\right)
$$

Under normal circumstances, $\alpha$ coefficient is above 0.70 , which indicates that the questionnaire is of good reliability and can be used for the next analysis. If $\alpha$ coefficient is lower than 0.35 , and the reliability is low, the stability of the questionnaire is insufficient, and it cannot be used. Among them, the reliability of the questionnaire is acceptable [16]. In this study, SPSS tool was used to analyze the reliability of the questionnaires used, and their consistency was checked to ensure the quality and credibility of the questionnaires. After inspection, the overall reliability of the questionnaire used in this survey was $\alpha=0.956$, and the reliability of development model $\alpha=0.954$, and the importance of reliability $\alpha=0.961$, all in line with Cronbach's standards, showing good reliability of the questionnaire.

(3) Development model result analysis

In this survey, men accounted for $45 \%$ of the total number of samples, and women accounted for $55 \%$, and the gender ratio is more balanced. In terms of age structure, the proportion of tourists aged 22-38 is the highest. From the point of education, undergraduates and college graduates accounted for the most. In view of residence, the majority of the tourists are Chinese. We can calculate the mean and standard deviation of the development model of 20 evaluation indicators, and sort them according to the average size. Through observation, 


\begin{tabular}{|c|c|c|c|c|c|c|c|}
\hline Indicator layer & Factor layer & $\begin{array}{c}\text { Very } \\
\text { dissatisfied }\end{array}$ & Dissatisfied & General & Satisfaction & $\begin{array}{c}\text { Very } \\
\text { satisfied }\end{array}$ & Average \\
\hline \multirow{2}{*}{$\begin{array}{c}\text { Rural Tourism } \\
\text { Catering }\end{array}$} & Rural features & 6 & 9 & 123 & 95 & 16 & 3.7 \\
\cline { 2 - 8 } & $\begin{array}{c}\text { Environmental } \\
\text { hygiene }\end{array}$ & 7 & 23 & 154 & 53 & 5 & 3.5 \\
\cline { 2 - 8 } & Price & 15 & 45 & 93 & 72 & 18 & 3.8 \\
\hline \multirow{2}{*}{$\begin{array}{c}\text { Rural tourism } \\
\text { accommodation }\end{array}$} & \begin{tabular}{c} 
Rural features \\
\cline { 2 - 8 }
\end{tabular} & 2 & 14 & 122 & 85 & 13 & 3.3 \\
\cline { 2 - 8 } & hygiene & 8 & 48 & 93 & 72 & 12 & 3.6 \\
\hline $\begin{array}{c}\text { Rural tourism } \\
\text { products }\end{array}$ & Rural features & 5 & 27 & 122 & 74 & 16 & 3.5 \\
\cline { 2 - 8 } $\begin{array}{c}\text { Indicator layer } \\
\text { Rural Tourism } \\
\text { Catering }\end{array}$ & Price & 8 & 64 & 103 & 53 & 3 & 2.2 \\
\cline { 2 - 8 } & Quality & 7 & 58 & 124 & 52 & 2 & 3.4 \\
\hline
\end{tabular}

Table 3: Ranking of development patterns of evaluation factors for intelligent rural tourism in China.

it can be seen that among the three-level indicators, tourists are more satisfied with the rural characteristics of tourism accommodation, rural characteristics and tastes of tourism and catering. The secondary models of development are the quality, price, and prices of tourism and catering. Paired sample T-test is a statistical method to test whether there is a significant difference in the overall mean of two paired samples. Paired samples can be two sets of sampled data for the same variable, and can also be considered as two different aspects of a problem [17]. To conduct paired sample $\mathrm{T}$ test, firstly we need to find the difference between each pair of samples, and then compare the mean and the average value of the 0 relationship, with weak sample no difference and the mean value should be near 0 , otherwise the sample is different [18]. In this study, the paired sample T test was used to analyze the difference between the importance of the questionnaire and the development model (the mutual comparison under the same indicator). If the difference was not significant, the importance of the indicator and the development model were examined. The performance of the entry is different, but conversely indicates significant, that is, and there is a certain distinction between the evaluation of the importance and the development model [19].

\section{Conclusion}

The rural tourism industry chain is different from the general manufacturing industry chain. This paper defines it as a chain-type relationship that supports various sectors of rural tourism activities through certain economic relationships. [20] In the rural tourism industry chain, there are horizontal links between industries, and various industries face consumers at the same time; any individual link in the rural tourism industry chain can directly provide tourism products for rural tourists, but they cannot provide complete tourism products. The rural tourism industry chain is different from the general industrial chain, and its chain core is diversified, and the core value of the rural tourism industry chain is the experience of rural culture. The digital background intelligent rural tourism development model core value should be rural cultural experience. [21] The value system of the rural tourism development model centering on the digital background intelligent rural tourism cultural experience is the basis for realizing the value-added of the rural tourism development model..

\section{Acknowledgement}

The research in this paper was supported by Henan Science and Technology Research Program (International Science and Technology Cooperation Area) Project in 2015: Research on Safety Management and Technology for Large-scale Festival Events (NO. 152102410043), and Henan Science and Technology Department Project in 2016: Innovative Research on Safety Management of Large-scale Festival Events (NO. 162400410023).

\section{References}

[1] Zheng Y, Li Q L. Research on innovation of rural tourism development mode under new situation.[J]. Journal of Anhui Agricultural Sciences, 2011.

[2] Wei H U. Research on Development Mode of Rural Tourism Based on Experience[J]. Journal of Anhui Agricultural Sciences, 2010.

[3] Huang Z, Lin L U, Qin S U, et al. Research and development of rural tourism under the background of new urbanization: Theoretical reflection and breakthrough of predicament[J]. Geographical Research, 2015.

[4] Wang H R, Han F L. On the Promotion of Rural Tourism in Heilongjiang Province Based on Intelligent Tourism Platform[J]. Journal of Qiqihar University, 2017. 
[5] Xi Y, Zhang Q. Research on the integration of urban and rural development in Nanjing under the background of global tourism[J]. Jiangsu Science \& Technology Information, 2017.

[6] Gao L A, Mei L, Liu J S, et al. Research on Rural Tourism Development under Spatial and Temporal Evolution of Tourism Flows Background_—Based on Investigation Data of Tangyu Town in Lantian County[J]. Resource Development \& Market, 2011.

[7] Zhou G. Research on Low-carbon Rural Tourism Development in Western Minority Regions in China --from the perspective of neoinstitutional economics $[\mathrm{J}]$. Interdisciplinary Journal of Contemporary Research in Business, 2013.

[8] Zhang S L, Ming-Hui L I, Wang Y, et al. Research on the Countermeasures and Patterns of Rural Tourism's Development under the New Rural Construction Background[J]. Sichuan Forestry Exploration \& Design, 2013.

[9] Juan-Mei L I. The Research on the Vocational Education Strategies of Rural Female Labor Force under the Background of Rural Tourism Development[J]. Adult Education, 2017.

[10] Sun J W. Discussion on Anhui Rural Tourism Development Model under the Background of Beautiful Countryside Construction[J]. Journal of Yangtze University, 2015.

[11] Yang C, Yang C. Research on rural tourism development model under the background of precision poverty alleviation[J]. Agro Food Industry Hi Tech, 2017, 28(1):1191-1195.

[12] Zhang L, Zhang M F, Tong Y. Research on the Development of Rural Tourism in Yunnan in the Background of Postmodern Tourism[J]. Value Engineering, 2014.

[13] Huang $S$ H. Research on the Interactive Development Mode of Rural Tourism and New Socialist Countryside Construction[J]. Journal of Anhui Agricultural Sciences, 2011.

[14] Puhe M. Integrated Urban E-ticketing Schemes Conflicting Objectives of Corresponding Stakeholders [J]. Transportation Research Procedia, 2014, 4:494-504. https://doi.org/10.1016/j.trpro.2014.11.038

[15] Yang Y, Xia X L, Xia M Z. Design and Practice of Rural Tourism Service Platform in Jiangning District of Nanjing Based on Intelligent Software Application[J]. Journal of Nanjing Institute of Industry Technology, 2017.

[16] Zhang J, Liu S S. Historical Architecture Regeneration Research Based on Rural Tourism Development[J]. Journal of Anhui Agricultural Sciences, 2015.

[17] Zhang X. Research on the Interactive Mode of Agricultural and Tourism Business to Promote Rural Development Vitality:A Case Study of the Model of "Fairy Fruit Tourism in Four Seasons" in Shangyu,Zhejiang Province[J]. China Development, 2016.

[18] Kaelin, Alyssa. Rural tourism development in Nepal: One village's experience of socioeconomic structural transformation[J]. Social Justice Research Center Grant Awards, 2013.

[19] Qiao L J, Wang J, Zhao J Y. Research on the Rural Tourism Development Mode Based on the "Tragedy of the Commons" about the Rural Tourism Resource_A Case of Hebei Province[J]. Tourism Overview, 2013.

[20] Lin-Zhong S U. Research on the Farmer Work Problem and Rural Tourism Development under the Influences of Financial Crisis[J]. Journal of Anhui Agricultural Sciences, 2009.

[21] Zhu G F. Research on Rural Tourism Development in Heilongjiang Province Against the Background of New Rural Construction[J]. Journal of Changchun Normal University, 2010. 
